\title{
Copyright, Legislative Aspect in Republic of Kosovo
}

\section{Msc.Labinot Osmanaj}

labi158@hotmail.com

\section{Msc.Egzone Osmanaj, Phd.Cand}

egzone.osmanaj@evun.eu

Doi:10.5901/ajis.2014.v3n2p213

Abstract

The topic which has been treated by the authors in this paper deals with copyright, its recognition and protection.Accomplished work made in this paper aims to offer new contemporary knowledge in the field of copyright relying on legal theory and legislation in Kosovo. Research questions which are raised in this paper are: - What is the content of a copyright, respectively, what rights are recognized to the creator of the work? - Is copyright considered as an unlimited right, or can it be limited? - If the limit is right, in which cases it can be limited? - In case of violation of copyright, how is the protection of copyright accomplished. - What is the duration of protection of copyright and is it the same as for economic as well as for moral rights or duration of protection varies depending on what the right question is addressed to? Related to raised questions in this paper explanations are given relying mainly on the provisions of the law on copyright and other related rights of the Republic of Kosovo.

Keywords: Author, rights, restrictions, protection.

\section{Introduction}

Nowadays legal regulation of copyright is not the only aspect of the internal law of each country,but it has taken wider international dimensions, thus becoming the object of legal regulation by various international agreements between participating states. That is, copyright as an absolute right, protected by international conventions and national laws of the said countries. Copyrights and other rights associated with it have been set out relatively late,particularly with judicial standards not only in Kosovo and Albania,but also in the world. Intellectual product as the object of copyright has been recognized late compared to other civil institutes. Although the idea for wealth benefit from intellectual creativity originates from the medieval, of the end of eighteenth century, for the first time copyright respectively aspect of its material benefit was recognized and was arranged especially by law.

\subsection{The object of the paper}

The object study of this paper is copyright, types of author's rights, restrictions of copyright, protection of copyright in terms of criminal, civil and administrative law and the protection of copyright through international conventions. The first part of the paper offers some general knowledge of copyright as the notion of copyright, the notion of the subject (the author) of the act, works on which copyright exists.

\subsection{The aim and methodology of the paper}

The aim of this paper is analytical review of copyright, highlighting the importance of copyright legislation provided by Legislation of Kosovo, particularly, its protection used methodology in this paper is mainly based on analyzing of current legislation which governs the copyright and other rights related to it. 


\section{General Knowledge on Copyright}

\subsection{Notion of copyright}

Copyright is defined as the totality of legal standards that which arrange social relations arising from the creation and evaluation of scientific, literary-judicial works.(Smaka,R,2010, P,429.)Copyrights are among the oldest forms of intellectual property rights and include the rights of authors in the field of literature, science and art.Copyright is a particular right which belongs to the author as the subject of intellectual property right of his/her work. This right belongs to the author mainly relying on the fact of creating the work, thus there are no prior demands to any administrative formalities.Professor, Abdulla Aliu defines the copyright in two meanings in the objective and in the subjective sense. In objective sense, copyright includes complexity of legal standards which stipulate legal relations for intellectual creativity in the field of literature, science, art, and other legal provisions which stipulate issues concerning or arising from intellectual product Whereas, copyright in the subjective sense of character represents the absolute legal authority regarding intellectual creativity that has the quality of a work.(Aliu ,A, 2010 P,60). The Law on the copyright 1978, which envisages literary authors, scientific and artistic copyright regarding their creativity, as defined by this law.Therefore,copyright includes a complex of general standards that govern the relations regarding the works accomplished by the authors.(Gams ,A,1986, P.89). The copyright, as it is understood,belongs to literary, scientific and artistic authors, considered by the law as the works of the author.In broader sense, literary, scientific,artistic work may be considered as the work of the author.

\subsubsection{Definition of the work as a creative intellectual}

Article 3 of the Law on copyright and other related rights of Kosovo, determines how the the work of author is considered from the areas of literature, science, art and other areas of works, regardless of type, method and forms of expression Whereas, relying to Article 4 of the Law "On Copyright and other Rights related to it " of Republic of Albania, every artistic work is original and intellectual creation of a natural person, materialized regardless to form and way of expression ,which is intends to affect human senses.

The piece of art is entitled to copyright protection as when meeting the terms foreseen by the positive rules of the country in which the protection of the author's right is requested. For a creation to be considered as a piece of art, the following three (3) essential conditions without which we can not have a piece of art should be met:

$>$ Creation should bare the character of an intellectual creation of an individual, or a group of people.

$>$ To be expressed in a concrete form that can be perceived by the human senses and make recognizable to man.

$>$ Creation has to be original.

If these conditions are met then the creation is entitled to legal protection regardless to its values. Even the title of a work is protected by copyright, as well as its title respective works. Copyright nature is of sucessional nature in relation to legal protection of work. The title is entitled to independent protection in the interest of the work.Taking of title is prohibited when causing confusion in relation to author of work. English law does not offer legal protection to title work and according to this law, its defense causes unfair competition. Whereas, French law provides that the title of the work is entitled to legal protection as a creative work, if original. In case of absence of authenticity, French law provides conditional distinction, so that no one can use the title for the individualization of the same type of work, of course, if it causes confusion. (Aliu ,A, 2010 P.61).

\subsubsection{Works on which copyright exists}

In legislation copyright works are explicitly calculated on bases copyright exist, thus copyright works are regarded as:..(See article 8 of the law on copyright and other related rights of Republic of Kosovo).

- verbal acts, such as speeches, lectures, and similar works that are verbally expressed;

o written works such as texts in books, brochures, newspapers and other texts in the field of literature, scientific and professional literature, and computer programs ;

- music works, with or without text, whether recorded as musical note sheet or in any other way;

○ theatrical works, musical and theatrical puppetry, including radio drama;

- pantomime and choreographic works; 
- screen works (film and television) and other audiovisual works (such as: audiovisual works);

- photograph works and works produced by a similar photography process, such as artistic photos, photo montage, photo-fliers, photographs by reporters;

○ works of art in the domain of drawing, painting, graphics, sculpture;

- architecture works, such as drawings, plans, models and construction works of architecture and engineering in the field of architecture, urbanism , landscape architecture and interior design;

○ works of screenplay;

○ the works of applied art and industrial design of graphics;

- cartographic works (maps, plans, sketches, three-dimensional) in the field of geography and topography;

- scientific nature presentations, educational or technical (technical drawings, graphs, charts, expert opinions, three-dimensional).

To obtain the copyright, creative activity production should take a concrete form, be materialized and perceived by the third party. Only by having an idea, without being materialized, it does not create copyright.

\subsubsection{Notion author of work}

Author of work is the subject of the right who has created the work, first or last name or whose nickname is written on work. The Law of Republic of Kosovo "On Copyright and other Related Rights" does not clearly define who will be the holder of copyright, who will be called the autor.

Thus, Article 13 stipulates that the author is a natural person who has created the work. Considering the object of copyright, the author can be any adult or minor, with or without the ability to act, provided that he has created a work that represents the object to the right of the author. Even the minors under the age of 14 I think may be eligible to the right of the author.In creation of a work may participate one or more individuals If only one person participates, then it is called the work of author. ( Albunesa, $U, P, 31)$. Whereas, when while creating of work participate more people as spiritual creators of work, with the same or different contribution, providing that the contribution is of original nature, creators of a work in this case are called co-authors.(The Law of Republic of Kosovo"On Copyright and other Related Rights", Article 15).In case when the work was created in collaboration with more people and work cannot not be divided, each copyright of author is entitled to copyright depending on given contribution. Only individuals can create author's works and only they can become authors, but when it comes to computer programs, as holder of copyright may be even judicial person.An author can publish work even by using his/her initials, or even nicknames.

\section{Content of Copyright}

Copyright contain:

- Exclusive powers to protect personal invulnerability of the author and the author's personality (hereinafter: the moral rights);

- Exclusive economic powers to protect the economic interests of copyright (hereinafter: the economic rights (property) of the author);

- Other copyright powers (hereinafter: the other rights of the author).(The Law of Republic of Kosovo"On Copyright and other Related Rights",Article 6).

A group of authors from Germany disagree on copyright partition, according to them there is no place in the division and differentiation of the copyright, material and moral authorizations, because according to them it is not true that moral rights protect the author's personality and the property rights toward his/her work, because while protecting the first one, the other one is also protected. Legal and property competence of the copyright includes authorization for the use of copyright and authority to exclude all others in the use of copyright if there is no agreement or if not allowed by the law.That is property rights of the authors; consist on copyright to use his/her own work. The use of work is performed through publishing, reproduction or multiplication, issuing on circulation, displaying, transfer, translation, etc. The moral rights of authors, consisting of his right to be recognized and accepted as the creator of the work, to oppose anyone who tends to abuse his/her work, or in any other form abuses and oppose to anyone who manipulates his work in the way that it insults or undermines his/her honor or prestige.(Bello,K,2011 P.11). The using of property right is limited to a certain number of years, depending on the type of work of the author, whereas the duration of moral rights in the work is unlimited.After the death of author, several powers of personal legal nature which are closely linked to the personality of the author stop functioning, whereas the accomplishment of some other powers can be transferred to inheritor.Powers 
which are closely linked to the personality of the author as for instance, rights to creation work replacement of work, retrieval of work from sale, and likewise.These rights can not be transferred to the inheritor.Such powers are called moral positive authorities, unlike the negative moral authority, which can be transferred.(Aliu,A 2010,P,68).

\subsection{Types of copyright}

The Law on Copyright and Related Rights of Republic of Kosovo has explicitly divided the copyright into two groups: economic and moral rights of the author which is treated into two separate chapters: Chapter IV addresses moral rights (Articles 17,18,20) in Chapter V treats economic rights or property (in Articles 21 and 22) , while Chapter VI deals with several other rights associated with the copyright, right of access and exposure, the right of the suite, the right of public lending, the right to special compensation (in Articles 36,38,39). In continuance we have introduced the contents of economic and moral rights of the author in tabular form.

Moral rights of the author
1. The right to be recognized as the author of a work.
2. The right of work publishing.
3. The right to remain anonymous or use the nickname.
4. The right to oppose any distortion, mutilation or alteration and any
other action contemptuous act that would violate the honor and name
of the author.
5. The right to penitence
6. Right to challenge the authorship ruled arbitrarily by the others

Economic rights of the author
1. The right of distribution
2. The right of distribution
3. The right of rent
4. The right public interpretation
5. The right of public broadcasting
6. The right of public communication
7. The right of public performance
8. Te right of radio/TV broadcasting
9. The right of further program broadcasting
10. The right of giving of work into public dispossal
11. The right of processing
12. The right of audiovisual adjusting

Table 1. Moral and economic rights (property) of the author.

\subsubsection{Moral rights}

The notion of moral rights is a notion that has arisen in countries which apply Civil Law, or Civil Rights. Countries differ from each other in terms of how they define and protect moral rights; France can be called the country which recognizes the most generous way these rights. Continental system gives priority to moral law in relation to property rights. Whereas, in countries applying common Laws there has been in general a reluctance to recognize moral rights. (Albunesa, $U$ $, P, 58)$.Law in these countries on copyright does not contain rules for the protection of moral right of the author, or consider subsiding, or second hand in relation to protection of property rights by fully setting out the sphere of exploitation of the work of the author, by enabling legal protection, firstly to work and then to its creator.( Koçi ,E,2003 ,P.123). Moral right of the author, according to its character is: absolute exclusive and strictly personal, and as a rule can be transferred only to achieve moral right of the author.Moral rights of the author are inextricably linked wit the author, until he is alive and even after his/her death.Only one part of them is transferred to the inheritor. Thus, such moral rights as the right to the name, appearances in public with nicknames are moral rights which are not transferable to author's in heritor.Whereas, moral rights to match the concept of avoiding the violence of a moral right are transferable to their inheritors, such as; co-others' right to challenge the co-others right, the right of name distortion, etc. In the first years of violations treatment by the Albanian judicial practice, after $90-\mathrm{s}$, was the case of publishing of Ismail Qemaili's diary by a publishing house without authorization of inheritors. The diary treated historical event but also addressed historical characters on human and even in on a personal level. The author's inheritors claim to provide the claim and requested to block the sale because, as the author himself had conceived it as a personal work. The claim was accepted in full and fully executed.(Albunesa, $U, P, 60)$.

\subsubsection{Economic rights (property) of the author}

The economic right (property) of the author relying on its nature is an exclusive and absolute right acting as erga omnes. (Gams,A,1986,P,97). In this view, the economic right is not distinguished from the moral rights of the author and they 
both belong author's right. Absolute character of author's right consists in that way to stop the exploitation of the work for which he hasn't mad any consent, regardless of who performs the execution. As task of economic rights (property) is to protect the legal interests of copyright material, it is understandable that property rights are transferable rights; the author has the right to transfer economic rights to the third person, and with or without any compensation. The transfer of economic rights (property) is one of the fundamental differences between moral and economic rights which arise from the character of necessity right to compensation which regulates the issues related to use and disposal of the work.

\subsection{Duration of protection of the moral and economic rights (property) of the author}

"The moral rights are protected permanently and the economic rights retained throughout the life and 70 years after the author's death."So it is obvious that the moral right emerges as a very important right of the author's right.Te copyright toward anonymously or with alias lasts 70 years from the date of lawful announcement of work.(The Law of Republic of Kosovo"On Copyright and other Related Rights",Article 62.2). The copyright in co-authors work of lasts 70 years from the death of co-author who died last. Copyright in a collective work lasts 70 years after the lawful announcement. Upon lawful announcement and allowed use.(The Law of Republic of Kosovo"On Copyright and other Related Rights",Article 62.4).

\subsection{Other Copyrights}

Besides for moral and economic rights, the Law on copyright and other related rights of Republic of Kosovo in Chapter VI (Articles $36,37,38$ ) addresses some of the other rights of the author, which will be presented in tabular form.

\section{Other copyrights \\ 1. The right of access and exposure \\ 2. The right of suite \\ 3. The right of public lending}

Table 2. Other copyright rights (except for moral and economic rights).

The right of access and exposure-The author has the right to access to the original or a copy of his/her work, which is in the possession of another person (hereinafter: the proprietor), when he needs it to reproduce or processed the work, and if he does not essentially affect the reasonable interests of proprietor. The author is entitled to require from the proprietor of artistic or photography original work to hand it over hand temporarily, for the purpose of exposure.(see article 37 of the law on copyright and other related rights of Republic of Kosovo).

The right to suite-In case of resale of an original work of art and after its first alienation by the author, he/she is entitled to be notified for resale, as well as the right to compensation in the amount as stipulated by the by law. Compensation for the suit right is payable in proportion to the original selling price in the market (tax not included), provided that the sale price exceeds the amount of $€ 2,000$.(see article 38 of the law on copyright and other related rights of Republic of Kosovo).

The right of pubic lending-The right of public lending is the right of the of the for author reasonable compensation, when the original or copy of a work is in disposal through a public institution, to be used for definite period and without direct t or indirect economic benefit. see article 39 of the law on copyright and other related rights of Republic of Kosovo).

\subsection{Limitations of copyright}

According to the law on copyright and other related rights of Republic of Kosovo restrictions of copyright are executed through two forms, which we have presented in tabular form.

Limitations of copyright
1. Free use of the work of the author without the author's permit and appropriate compensation;
2. The use of author's work without the author's permit, but with appropriate compensation;

Table 3. Copyright limitations 


\subsubsection{Free use of copyright without author's permit and appropriate compensation}

Law on copyright and other approximate rights o Republic of Kosovo in chapter VII has made separated the cases of free use of copyright without author's permit and appropriate compensation into two groups which we have appeared in tabular form as follows.

\begin{tabular}{|l|l|}
\hline $\begin{array}{l}\text { General cases of copyright use without the author's permit and } \\
\text { appropriate compensation }\end{array}$ & $\begin{array}{l}\text { Special cases of free use of copyright and author's right } \\
\text { without the author's right and appropriate compensations }\end{array}$ \\
\hline $\begin{array}{l}\text { Free use with applying of official procedures } \\
\text { Free use for teaching needs }\end{array}$ & Free use in cases of public information \\
\hline Free use with self and private reproduction & Free use in cases of quotations \\
\hline Free use with radio/television recordings & Free use in form of free processing \\
\hline Free use on occasion of ceremonies and celebrations. & Free use of works in public places \\
\hline & $\begin{array}{l}\text { Free use in cases of equipment demonstration. } \\
\text { Free use in cases of data bases }\end{array}$ \\
\hline
\end{tabular}

Table 3. General and special cases of copyright limitations without author's permit and appropriate compensation.

\subsubsection{General cases of copyright limitations without author's permit and appropriate compensation}

\subsubsection{Free use with application of official procedures}

It is a free to use a work for the purposes of public security or regular procedures of a proper performance or reporting of administrative, parliamentary or judicial proceedings, without necessity to record the name of the author and the source where the work was taken from.(See article 43 of the law on copyright and other related rights of Republic of Kosovo).

\subsubsection{Free us for teaching needs}

Only for the purpose of illustration for teaching in schools of all levels, whereas in non-commercial goal is free of use: public interpretation of works published if it is a direct form of teaching in the school; public interpretation of published works on free of charge school celebrations, provided that the performers are not compensated for this; communication of works by phonograms and videograms for teaching purposes; reproduction short parts of published works, for purposes of direct teaching or examinations; rebroadcasting in school broadcast television; further reproduction of educational television programs on phonograms or video-gram,only for purposes of direct teaching within school premises. (See article 44 of the law on copyright and other related rights of Republic of Kosovo).

\subsubsection{Free use with private self and reproduction}

According to the law of copyright and related rights of Republic of Kosovo, the reproduction of published works by a natural person is free of use if made in three copies. ${ }^{28}$ Public libraries, public archives, museums and educational or scientific institutions, can freely reproduce the work in any medium, whether the specimen if reproduction is made by using available sample and without any direct or indirect commercial interest.(See article 45.3 of the law on copyright and other related rights of Republic of Kosovo).

\subsubsection{Free use with transitive radio-television recordings}

Broadcaster which owns work permission may freely reproduce with its own facilities broadcast this work on phonogram videogram and broadcast it again. Recording of work should be absolutely deleted within one month from the date of work broadcasting ,and if the value of extraordinary documentary archive can be delivered to the public and for this the author should be informed in advance.(See article 47 of the law on copyright and other related rights of Republic of Kosovo). 


\subsubsection{Special cases of copyright limitations without author's permit and appropriate compensation}

\subsubsection{Free use in cases public information}

The law of copyright and other associated rights of Republic of Kosovo, Article 50 determines the cases in which reproduction is free in order to have free access to information of public character:

- reproduction, distribution and communication to the audience of seen or heard work as a part of the event being reported, but not to the extent of reporting on events of the day;

- reproduction and communication for the audience, short presentation, in the form of a review or any other content reference copyright of published works;

- use parts of several different commentaries and

- other published articles in the media in the form of daily coverage (press statement);

- the use of political speeches and other speeches held in public debates,

- to the extent of informational purpose.

\subsubsection{Free use in form of free processing}

Processing work is permissible: if it has to do with private or other processing, which is not available to the audience; transformed into a parody or caricature, if it does not create or cannot create confusion as to the source; if the transformation requires the authorized use and lawful purpose. (See article 53 of the law on copyright and other related rights of Republic of Kosovo) .

\subsubsection{Free use of works in public places}

Works permanently placed on public streets, squares, parks and other places where the general public has access, can be freely used. Although, the use of these works is not allowed in three-dimensional form or for the same purpose as original or commercial work nor even directly or indirectly.(See article 54 of the law on copyright and other related rights of Republic of Kosovo).

\subsubsection{The use of the copyright work without the author's permit of the but with appropriate compensation}

According to the law on copyright and other rights associated Republic of Kosovo, the use of a work without the author's permit, but with appropriate compensation which can be made in the following cases: with books and textbooks reading, television comments and press articles, broadcasting of phonograms published and social institutions. With books and textbooks reading that include works of authors dedicated to teaching in schools of all levels with permitted appropriate compensation is allowed the reproduction and collecting of short parts of published work author, respectively, of works published separately in the field of fine arts, photography, architecture, art and industrial design and cartography. (See article 57 of the law on copyright and other related rights of Republic of Kosovo).Public communication is permissible with appropriate compensation payment,reproduction and circulation with means of public information, certain comments on radio or television, photographs and newspaper articles, which were published on other means of information if related to current economic, political, if they do not contain the clause the reservation of the copyright.(See article 58 of the law on copyright and other related rights of Republic of Kosovo).Transmitters are allowed to broadcast works from published phonograms provided that prior to broadcasting to have entered it a contract related to amount terms and the way of payment on collective association.Also with appropriate compensation payment reproduction and rebroadcast broadcaster emissions aged care for the elderly, hospitals ,prisons and similar social institutions is permissible. (See article 59 and 60 of the law on copyright and other related rights of Republic of Kosovo).

\section{Protection of Copyright}

\subsection{Protection of copyright in national terms}

All copyrights as well as economic rights are entitled to legal protection. Protection of author's creativity, is of particular significance because it promotes creativity, creates economic security and interests and with protection economic 
interests are benefited According to copyright other related rights to it,depending on committed violation,protection of copyright can be accomplished in the following ways: in civil, criminal and administrative aspect.

\subsubsection{Legal-civil protection}

If no agreement is reached for the in addition to violation of copyright between the parties, the interested persons may approach the civil court for resolving the dispute.Legal copyright law means that along with protection in violation of the copyright, the same may also require compensation of damage.Compensation of damage includes loss consequences and lack of profit.If the violator apart from the damage he/she has caused to another party has also gained a significant profit, the injured party may ask the court to calculate this profit for compensation of damage.( See more,Aliu,A,2010).In cases where violation of moral rights of the owner of copyright, although it was not caused any material damage, the court may decide in favor of the author, to be pay real rewards caused due to violation of his personality,honor is immaterial damage, if it finds that the circumstances of the case, particularly the degree of the violation and its duration will justify the same.

\subsubsection{Legal protection offenses}

Copyright also can be protected through criminal process, namely violation of copyright is a criminal offense. Criminal protection is stipulated wit the laws for copyright and also with penal code. Thus, Criminal Code of Albania as stipulated in Article 148 determines the following: "Publication or wholly or partly use of own name for a literary, musical, artistic or scientific work, that belongs to another, constitutes a criminal offense fined with or imprisonment up to 2 years ".Whereas, the Law on copyright and other rights of the Republic of Kosovo approximate predicts "that the one who publishes in his own name, in the name of another or otherwise communicates the work or interpretation of someone else to audience,criminal offense punishable with imprisonment of three months to three years," and in this way also apply with Criminal Code of Kosovo.Or the one who during the use of author's work or interpretation deliberately neglects to show the name, alias or author's mark, when required by this law, a criminal offense is punishable by fine or imprisonment up to one year. (See article 192.2 of the law on copyright and other related rights of Republic of Kosovo).He/she also distorts, cripples or otherwise harms author's work, or others interpretation, and as such publishes or communicates to the public, or the one who work or the interpretation of the author communicates to the public in a humiliating manner, provided that each of these actions violate the honor and reputation of the author or performer, criminal offense is punishable by fine or imprisonment up to one year.(See article 192.3 of the law on copyright and other related rights of Republic of Kosovo.

\subsubsection{Legal-Administrative Protection}

By the law is also stipulated the responsibility of legal persons who are convicted of offenses, including a fine in cash when making violation of copyright. In these cases the person in charge that works for the employer is responsible I this way, the Law on copyright and other related rights of Kosovo provides that a fine of at least $€ 500$ to $€ 50,000$ is punished legal person for offenses in the context of his/her activity in a business with others, has been using without permission of the copyright the work or subject matter of related rights.

\subsection{International Conventions which protect copyright}

Copyright is entitled to international protection. With international law are created standards through which the intellectual property means the copyright is protected and is secured as well as other rights of property character. Intellectual creativity shaped character in the works of author is of universal character. Verbal works are translated into foreign languages, stage works are performed throughout the world, works of art are exhibited in various places, stage performances appear in different places. There are some international conventions that arrange copyright, some of them are mentioned bellow:

1. Convention of Bern 1986

2. Universal Convention on Copyrights

3. International Convention of Rome 1961

4. The Universal Convention of Paris for copyright and its two Additional Protocols, 1971 
5. Convention for the Protection of Producers of Phonograms against unauthorized reproduction of their phonograms 1971

6. Geneva Treaty of 1978

7. Convention of Madrid 1979

8. WIPO Treaty on copyright 1996.

It is also worth emphasizing that the European Union has developed a number of directives in the field of copyright. As it is known directives are acts are institutional binding for states members. It means that the guidelines e adopted by the EU institutions, are included in internal legislation of state members.Namely, directives of EU in the field of copyright terms have led to modification of national legislation for the setting out and protection of this right. ${ }^{1} \mathrm{EU}$ Directives adopted in the field of copyright and other rights are related to:

1. 93/83/KE Directive dated September 271993 "On the coordination of rules for copyright and related rights applicable to satellite broadcasting and cable retransmission."

2. 2001/84/KE Directive of the European Parliament and Council dated September 272001 "On the resale right for the benefit of the author of an original artwork."

3. 2006/115/KE Directive of the European Parliament and Council dated December 122006 " On the right of lease and debt as well as certain rights related to copyright in the field of intellectual property "(codified version of $92 / 100 / K E E)$.

4. 2006/116/KE Directive of the European Parliament and Council dated 12 December 2006 "On the protection of copyright and other rights related to" (codified version of 93/98/EC).

5. Directive 96/9/EC of the European Parliament and Council dated March 111996 on the legal protection of databases".

6. 2009/24/KE Directive of the European Parliament and Council dated April 23, 2009

7. "On legal protection of computer programs."(See more Albunesa ,U.P,71).

\section{Instead of Completion}

Institute of copyright in Kosovo is recent. Significant developments in the field of copyright have been in the post war period years in Kosovo.Legal infrastructure started to constitute in during the year 2000 regarding the right of copyright and other related rights, so in 2004 the Assembly of Kosovo adopted the law on copyright and other similar rights, the law which is currently in force. Apart from the Law on copyright and other similar rights, the Assembly has adopted several other laws which stipulate e intellectual ownership as: Patent Law (04/L-029), the law of Trade Marks (04/L-026), Industrial Design Law (No. 04/L-028). Apart for legal infrastructure, institutional infrastructure was also constituted initially was developed Industrial Property Office within the Ministry of Trade and Industry in 2007, then Office for Copyright and Related Rights in the Ministry of Culture, Youth and Sports established in 2010, but in 2011 started operating. The main task of the Industrial Property Office is receiving applications for the registration of patents, trademarks and industrial designs, performing of examinations and recognition of rights, as well as the management and publishing rights. Office became operational on November 192007 and since then the office has received approximately 20,000 applications for registration of industrial property premises and most of them have to do with trademarks. This office currently has six employees and there is a need for increasing the number of office employees in order to be able to perform all duties as stipulated by the laws. IP has a significant role in the system of IPR protection, and is also responsible about public awareness for PI. This office reports to General Secretary of MTI.During 2012 IPO received 11.220 requests of various kinds, such as: for trademarks 1,274 requests, 82 requests for patents, industrial design 14 requests and 9.850 requests for changes, additions, remaining in force, waiving, continuance, etc.Office for Copyright and Related Rights is an administrative body which is established and is functioning within the framework of appropriate Ministry of Culture. Basic activities of Office include:

- Granting of permission for administration of collective associations of rights;

- Obtaining the permit granted to the Association for collective administration of rights in the case of not meeting the criteria as stipulated by the law;

- Supervising of operation and activities of associations for collective administration of rights;

1 Procesi i ratifikimi të direktivave në fushën e të drejtës se autorit nga ana e shteteve anëtare nuk ishte i lehtë,për shkak se shtetet anëtare jo vetëm që kanë legjislacione të ndryshme në ketë fushe por edhe i perkasin familjeve të ndryshme ligjore. 
- Promote and undertaking of activities to provide relevant information to authors, holders of rights and wide public concerning copyright and related rights;

- Monitoring of international legislation and making recommendations regarding the field of copyright and related rights.

Therefore,we can conclude that during the last decade in Kosovo a significant progress has been made in the creation of legal and institutional infrastructure in the area of intellectual property, but many are still required to be done about security and compliance mechanisms for the protection of copyright in practice.In Kosovo there is a great need to create a culture of respect for the intellectual property rights.Common citizen in Kosovo does not have sufficient information about the existence of patents, copyrights or trade brands. Therefore it is of great importance to raise the awareness in society about the role and importance of protecting and respecting the rights of intellectual property, and its importance toward economic development, protection of investment and its impact on rising of citizens' welfare.

\section{References}

Aliu,A.(2010) Copyright, Prishtina.

Aliu ,A.(2010) The Civil Law,Pristina.

Gams A.(1986) Introduction to Civil Law , (The General Part), ,Prishtina.

Koçi .E.(2003) ."Intellectual Property, Copyright and Trademarks ",Tirana.

Uarda.A. E copyright in Albanian and European legislation, their approach Tirana. (http://www.doktoratura.unitir.edu.al/wpcontent/uploads/2014/03/Doktoratura-Uarda- Albunesa-Instituti-Studimeve-Europiane.pdf).

Smaka.R.(2008) Of Business Law, Royal University Illyria, Pristina.

Legal Acts

Law No. 2004/45 on Copyright and Related Rights, promulgated by Regulation No. 2006/46 dated August 242006.

Law on copyright and related rights. Law No. 04/L-065 .2011.

Law on Copyright and other rights associated with the Republic of Albania, no. 9380, dated April 282005.

Criminal Code of Albania.

Criminal Code of Kosovo. 